Wzniostośc i makabra w literackich obrazach śmierci, red. Michał Kuran, Łódź 2014, „Analecta Literackie i Językowe", t. IV.

\author{
Olga SZadkowska ${ }^{1}$ \\ Uniwersytet Warszawski
}

\title{
ONIRYCZNA WĘDRÓWKA DUSZY ZMARŁEGO WokóŁ ZJaWIenia EmiLKi Jana PaWŁa Woronicza
}

Chciałabym przyjrzeć się utworowi Jana Pawła Woronicza, Zjawienie Emilki. Dzieło to często odczytywane jest jako poemat mesjanistyczny ${ }^{2}$, w którym przyszły prymas Królestwa Polskiego wykłada swój pogląd na historiozofię i umieszcza zapowiedź odrodzenia Polski. Wykorzystywanie motywów proroczych było charakterystyczne dla epoki romantyzmu, niemniej jednak interpretacja dzieła Woronicza jako preromantycznego jest zbyt dużym uproszczeniem. Korzenie tego utworu wydają się bowiem wyraźnie antyczne, czego przykładem może być wykorzystanie motywu wędrówki duszy zmarłego po zaświatach.

Przeświadczenie, że podczas marzenia sennego dusza ludzka unosi się i odwiedza rejony dostępne tylko istotom wyższym, stało się niewątpliwą inspiracją dla późniejszej tradycji literackiej ${ }^{3}$. Snom często towarzyszą wizje, w których dusza człowieka powoli odrywa się od ciała i zbliża się do Boga bądź do bóstwa. Platońska wizja zmarłego żołnierza nakreślona w X księdze Państwa, w której Er odwiedza zaświaty i wraca, by opowiedzieć, co widziała jego dusza podczas wędrówki, może stanowić drugi popularny trend $\mathrm{w}$ literaturze ${ }^{4}$. Jest nim przeniesienie się duszy zmarkego, który odwiedza krainę

\footnotetext{
${ }^{1}$ Olga Szadkowska - doktorantka w Zakładzie Edytorstwa i Stylistyki w Instytucie Polonistyki Stosowanej na Wydziale Polonistyki Uniwersytetu Warszawskiego. Absolwentka filologii polskiej na Wydziale Polonistyki UW (specjalizacja zawodowa: filologia dla mediów). Stypendystka programu LPP Erasmus na Universita' degli studi di Roma 'La Sapienza' w Rzymie (2009-2010). W czerwcu bieżącego roku otworzyła przewód doktorski. Tytuł rozprawy: Alfieri w Polsce. Problemy recepcji. Prowadzi zajęcia z historii edycji polskiej literatury pięknej oraz zajęcia z historii edycji literatury powszechnej z elementami translatologii. Jej zainteresowania naukowe koncentrują się wokół literatury oświeceniowej, polsko-włoskich związków literackich, wyzwań współczesnego edytorstwa i historii przekładu.

${ }^{2}$ Zob. Przemiany tradycji barskiej, red. Z. Stefanowska, Kraków 1972 oraz M. Nesteruk i Z. Rejman Wstęp, [w:] J. P. Woronicz, Pisma wybrane, oprac. M. Nesteruk, Z. Rejman, Wrocław 2002, BN I 299.

${ }^{3}$ Taka koncepcja ma swoje antyczne pochodzenie. O duszy wznoszącej się podczas snu pisał Platon, m.in. w Państwie, Timajosie, Teajtecie. Również Posydoniusz w zachowanych fragmentach traktatu o marzeniach sennych pisze o transgranicznym momencie, w którym ciało jest wiotkie, niezdolne do czynu, a dusza unosi się do wszechświata. Podróż w zaświaty duszy cnotliwej opisywał również Plutarch w Oodwlekaniu kary przez bogów. O wszystkich tych przypadkach lotu umysłu nad kosmosem pisze Joanna Zagożdżon, porównując motyw snu antycznego ze średniowiecznym i renesansowym ujęciem tej problematyki, zob. J. Zagożdżon, Sen w literaturze średniowiecznej i renesansowej, Opole 2002, s. 53-55.

${ }^{4}$ Platon, Państwo, t. 2, przekł., wstępem, objaśnieniami i ilustracjami opatrzył W. Witwicki, Warszawa 1958, s. 87-100.
} 
nadziemską, a następnie dostaje polecenie, by zanieść ludziom wiadomość o tym, co ujrzał. Podobnie jak Er jest świadomy podczas swojej wędrówki, tak i zmarła Emilka, która ukazuje się siostrze, jest świadoma swojej roli, jaką pełni, przynosząc ludzkości obraz wszechświata i objaśniając znaki boskie. Zjawienie Emilki nie jest tylko utworem konsolacyjnym, na co wskazują słowa bohaterki „dla waszych kłopotów pociechy”. To głęboko zakorzeniony w tradycji wizjonerskiej i proroczej utwór, który nie może uciec od platońskiej koncepcji wznoszącej się duszy, ogarniającej całość wszechświata i schodzącej na ziemię pod postacią alegorycznej wizji. Również kategoria duszy, która błąka się po świecie i nie może znaleźć ukojenia, dopóki nie spełni swojego zadania, ma antyczną proweniencję $e^{6}$ Podział na dusze, które są rozumne i którym może zostać objawiona prawda podczas snu oraz takie, którym przeznaczone jest tylko doznanie biologicznego snu bez proroczej wizji, przedstawił Platon zarówno w Timajosie, jak i w Państwie. Stwierdza, że sen prawdziwy, wizjonerski, który pozwala na oglądanie przyszłych wydarzeń, może przytrafić się tylko duszom czystym i obdarzonym rozumnością. Przywodzi to na myśl podróż duszy Emilki, która objawiając się siostrze we śnie, pełni następujące funkcje: od konsolacyjnych, poprzez profetyczne, aż po odsłonięcie skrywanej przez siłę wyższą prawdy i przekazanie jej w tym przypadku śpiącemu.

Warto zastanowić się nad tym, jakie są podobieństwa i jakie różnice w ujęciu chrześcijańskim (Zjawienie Emilki) oraz starożytnym tej specyficznej wędrówki, jaką jest wędrówka duszy po zaświatach. Czy można mówić o kontynuacji tradycji platońskiej (czy też neoplatońskiej jak w przypadku Makrobiusza) u Woronicza, czy raczej jest to swoistego rodzaju gra z konwencją?

\section{ANTYCZNE KORZENIE UTWORU WORONICZA}

Zjawienie Emilki na petni kwadry II lunacji XIII cyklu stonecznego XI — już sam tytuł utworu odnosi się ściśle do sprecyzowanej wiedzy astrologicznej. Całość wizji dotyczy dwóch stanów konstelacji, w jakie wchodziły Bliźnięta. Według rachuby kalendarzy astrologicznych, zjawienie zostało obliczone na dzień 25 grudnia 1795 roku$^{7}$.

${ }_{5}^{5}$ J. P. Woronicz, Zjawienie Emilki, [w:] tenże, Światynia Sybilli i inne utwory, oprac. R. Dąbrowski, Kraków 2002, s. 26-42.

${ }^{6}$ Dokładny opis rodzajów duszy ludzkiej oraz funkcji, jakie pełniła podczas tworzenia się marzeń onirycznych, objaśnił Platon w Timajosie, zob. Platon, Dusze gwiazd. Metempsychoza. Tworzenie organizmu ludzkiego, s. 51-60 oraz Dusza śmiertelna i jej organizm, [w:] tenże, Timajos, Kritias albo Atlantyk, przekł., wstęp koment. i skorowidz P. Siwek, Warszawa 1986, s. 94-112.

${ }^{7}$ Taką datę podają M. Nesteruk i Z. Rejman. Zob. J. P. Woronicz, Pisma wybrane, s. 60. Badacze zgadzają się co do tego, że konstelacje Zodiaku są dla Woronicza symbolem stosunków europejskich oraz zapowiedzią niepodległych zdarzeń, różnie jednak interpretują poszczególne postaci. W przypisach do Zjawienia Emilki M. Nesteruk i Z. Rejman podają wersje Kamykowskiego oraz Drogoszewskiego, zob. J. P. Woronicz, Pisma wybrane, Warszawa 1993, s. 662. Powołuje się na to również J. Gorzelana, analizując polskie kalendarze tego okresu, por. J. Gorzelana, Niektóre jezykowe cechy horoskopu w poemacie Zjawienie Emilki ks. Jana Pawła Woronicza, [w:] Jezzk doświadczenia religijnego, red. G. Cyran i E. Skorupska-Raczyńska, t. 1, Szczecin 2008, s. 230. 
Śpiącej Józi ukazuje się więc zmarła siostra, zmarła przedwcześnie, jeszcze jako dziecko. W pierwszych momentach swojego objawienia Emilka tak przemawia do siostry:

Jakże twe niedołęstwo marny sen posiada! [...]

Ale chociaż twe członki słabości poddane,

Dusze jednak nas obu skazą nie zmazane

Mogą się i rozumieć i słyszeć i widzieć $[\ldots]^{8}$.

Sen zostaje przedstawiony jako możliwość, dzięki której siostry znów będą mogły się porozumieć. Owo spotkanie przebiegnie w określonej formie, tzn. zmarła Emilka ukaże się Józi i opowie o tym, co widziała i co ma do przekazania ludzkości. Ważnym elementem jest również przymiotnik określający dusze dziewczynek — są one nieskazitelne. W takim wypadku spełniony jest podstawowy warunek peregrynacji dusz podczas „prawdziwego snu”. Jest to dusza godna, przygotowana, której może zostać objawiona prawda pod tajemniczą postacią alegorycznej wizji. Natura bowiem zdradzała swoje sekrety tylko wybranym, tylko tym, którzy posiedli zdolność pojmowania prawd. Utożsamiane są one z czterema cnotami: fortitudo (męstwem), iustitia (sprawiedliwościa), prudentia (roztropnościa) i temperantia (wstrzemięźliwościa). Taką klasyfikację teorii etycznej wykłada Makrobiusz w utworze Commentarii in Somnium Scipionis ${ }^{10}$. Według jego koncepcji (którą zaczerpnął od Cycerona), każdy człowiek dzięki kształtowaniu swojego charakteru zdobywa mądrość i może osiągać kolejne stadia duchowego rozwoju. Moralny ład, zarówno wewnętrzny, jak i zewnętrzny, daje swoiste zapewnienie, że zasługi podczas ziemskiej egzystencji nie przepadną wraz z jej zakończeniem.

Emilka rozpoczyna opowieść o swojej wędrówce po zaświatach, o tym, jak wygląda „miasto na górze wielu gór wzniesione / Jako kryształ światłością Boga rozświetlone” ${ }^{11}$. Należy zwrócić uwagę na poetycki krajobraz, który rozpościera się przed czytelnikiem, mieniący się tysiącami barw, wypełniony światłem, niezwykle sensualny, plastyczny. Obraz, który - nawet mimo woli - czytelnik widzi i czuje: czuje zapach wiosny, która cały czas panuje w Raju, i jest świadkiem gry świateł, które odbijają się od drogocennych kamieni. Jest coś takiego w tym opisie, co oślepia, nie tylko zachwyca swoim spokojem, harmonią, ale wręcz magnetyzuje, przyprawia o zawrót głowy. Ta specyficzna taktyka plastyczności obrazu przywodzi na myśl krainę barw i iluminacji przedstawioną w historii o Erze, który zamyka X księgę Państwa Platona. Bohaterem mitu jest żołnierz nieprzytomny przez trzynaście dni wskutek ran odniesionych na wojnie. Dopiero w momencie umieszczenia jego ciała na stosie budzi się i opowiada

\footnotetext{
${ }^{8}$ J. P. Woronicz, Zjawienie Emilki..., s. 27.

${ }^{9}$ Jest to termin użyty przez Makrobiusza, rozróżnia on bowiem dwa typy snów, somnium (sny prawdziwe, alegoryczne) oraz insomnium (fałszywe, powstają pod wpływem czynników psychosomatycznych), zob. W. H. Stahl, Wstęp, [w:] Commentary on the Dream of Scipio, Nowy Jork 1990, s. 9.

${ }^{10}$ Makrobiusz, Commentary on the Dream of Scipio, Nowy Jork 1990, s. 120-124.

${ }^{11}$ J. P. Woronicz, Zjawienie Emilki..., s. 27.
} 
towarzyszom, co widziała jego pozornie zmarła dusza. W czasie chwilowej śmierci dusza Era podróżowała po zaświatach tak długo, aż doszła do miejsca przypominającego Sąd Ostateczny. Odbywało się tam rozdzielenie dusz na sprawiedliwe i niesprawiedliwe. Dalej Er widział łunę światła, przez której środek przechodziły końce więzów niebieskich. Całość wprawiało w ruch wrzeciono bogini Konieczności, tworząc osiem kręgów tak, że jeden tkwił w następnym. Układ ośmiu sfer niebieskich, które wraz z obracającymi się planetami spoczywały na kolanach bogini Konieczności, jest nietypowym przedstawieniem mechanizmu wszechświata, a Platon w X księdze Państwa poświęcił temu opisowi bardzo dużo miejsca, podobnie jak sposobowi ujęcia czynnika determinującego los ludzkiej duszy ${ }^{12}$. Wokół bogini przędły nici przeznaczenia jej córki, udostępniające duszom ludzkim ich przyszłe losy. Tak wyposażona dusza — ze świadomością swojego przyszłego życia — była wysyłana do wypełnienia swojej powinności na ziemi ${ }^{13}$.

Punkt kulminacyjny opowieści platońskiej stanowi zbliżenie się duszy do osi kosmosu: następuje wtedy gra świateł i swoistego rodzaju spektakl przedstawień, a obraz świata ulega gwałtownemu przekształceniu i traci ostre rysy. Kosmos wydaje się wizyjnym światem stworzonym gdzieś na granicy wyobraźni i jaźni. Warto również zwrócić uwagę na miejsce, z którego dusze rozglądają się po niebieskich przestworzach. Przemieszczające się dusze obserwują niejako model wszechświata z boku, co musi sugerować to, że nie opuszczają one powierzchni Ziemi. Dusza umarłego nie oddala się od globu, może jedynie w momencie pielgrzymki znajdować się bardzo blisko sferycznej szczeliny, skąd ma widok na model przestrzeni kosmicznej. Komponuje się to z platońską wizją „wzroku wewnętrznego”. Platon bowiem przykłada ogromną wagę do zmysłu wzroku, światła, oglądania, czy właśnie — jak w przypadku snu — podglądania ${ }^{14}$. Tak oto przedstawia się wizja dobrej duszy, która zamknięta jeszcze w ciele, wzbija się ponad zmysłowość i wpatruje się w objawione rzeczy niebieskie.

Analogiczna plastyczność obrazowania cechuje Sen Scypiona, na którego podstawie Makrobiusz stworzył swój neoplatoński komentarz — Cyceron poświęcił wiele miejsca opisowi kosmosu, odwołując się do platońskiej koncepcji wszechświata. Widać więc gwiazdy krążące w swych orbitach ożywione przez ducha boskiego, a także słychać pewnego rodzaju symfonię kosmosu. W opisie cycerońskim nie brak bowiem muzycz-

\footnotetext{
${ }^{12}$ Jak zauważa Henryk Podbielski, w najsławniejszym micie eschatologicznym Platona, czyli w micie o Erze, rozgrywa się prawdziwie kosmiczna scena Sądu Ostatecznego. Zwraca on uwagę na to, że tam, gdzie dociera Er, znajduje się samo centrum, jądro kosmosu. Podbielski zaznacza również, że chiazma, wydobywająca się przez otwory, jakimi przedostają się dusze, unaocznia różne typy podróży, które odbywają owe dusze. W artykule Podbielskiego wyraźnie zostaje podkreślony związek między ładem kosmicznym, koniecznością a budową świata: „Wykorzystuje Platon formę mitu do przedstawienia niemożliwej do zweryfikowania, wizyjnej i nasyconej symboliką koncepcji budowy świata, koncepcji, która stoi w pełnej zgodzie i podbudowuje jego wykład o sprawiedliwym państwie”, zob. H. Podbielski, Obraz zaświatów $w$ dialogach Platona, „Roczniki Humanistyczne”, t. 54-55: 2006-2007, z. 3, s. 51.

${ }^{13}$ Platon, Państwo..., s. 87-88.

${ }^{14} \mathrm{O}$ wewnętrznym oku pisze Platon w wielu swoich dialogach: Timajosie, Fajdrosie, Fedonie, Gorgiaszu oraz Państwie, cyt. za: J. Zagożdżon, Sen w literaturze..., s. 53.
} 
nych akcentów — kręgi niebieskie, podczas kołowego biegu wydają z siebie wysokie i niskie akordy, tworząc harmonię sfer. Ten niewątpliwie fascynujący i niezwykły opis pokazuje, jak bardzo przytłaczający wydaje się ogrom wszechświata i jednocześnie, jak mało ważne są sprawy doczesne wobec tego ogromu. Wszystko to uznał Afrykańczyk za dowód znikomej wartości sławy ludzkiej.

Podobnie przedstawia się sposób obrazowania Woronicza w opisie Drogi Mlecznej, czy w opisie wszechświata „w majestacie Bożym zanurzonym”. Odgrodzony jest on dwunastoma bramami, „niosącymi dwunastu sławnych pokoleń imiona” ${ }^{15}$. Widać, że Królestwo Niebieskie jest jak gdyby usytuowane poza sferami niebieskimi, góruje nad nimi. Jest to więc przestrzeń, która, będąc częścią wszechświata, jest sama w sobie zasadą nadrzędną. Podobnie sytuację przedstawia Platon. Zarysowany w X księdze Państwa system planetarny jest pewnego rodzaju mikrokosmosem, jest to niejako objawienie, wizja w wizji, jedno z najbardziej intrygujących przedstawień astrologicznych. Kontynuację dostrzec można w późniejszej tradycji antycznej, np. w Śnie Scypiona, ale również w tak odległym od platońskich czasów Zjawieniu Emilki. Powstaje pytanie, na ile Woronicz świadomie korzystał z platońskiej wizji, czy mógł on czytać Platona, czy mógł się mitem Era inspirować? Chociaż, jak zauważa Zbigniew Nerczuk, Platon nie był bliski filozofom oświecenia i prawdziwie oczarowuje on dopiero romantyków ${ }^{16}$, to jednak warto zwrócić uwagę na pewne wskazówki, które mogą pokazywać nową drogę interpretacji tego zjawiska. Jak zaznacza Tomasz Mróz, Polacy, pisząc o Platonie, dobrze orientowali się w literaturze przedmiotu, zwłaszcza w literaturze niemieckiej. Ich dzieła nie były jednak jedynie recepcją i dyskusją nad osiągnięciami badaczy niemieckich czy francuskich, gdyż toczyli spory o Platona także w środowisku polskim. Recepcja Platona w Polsce rozwijała się więc własnym torem - nie będąc przy tym w swych inspiracjach izolowaną od badań zachodnich ${ }^{17}$. Wśród poruszanych zagadnień dominowały sprawy obyczajowe, pedagogiczne, matematyczno-przyrodnicze i dotyczące filozofii społecznej. Lektura dialogów Platona oraz określone ich odczytanie wydawały się niejednokrotnie remedium na bolączki wieku. W Polsce odczytywano go jako fantastę, demagoga, socjalistę, praprzodka chrześcijaństwa, spirytualistę, duszpasterza, odkrywcę prawd mesjanizmu polskiego. To zestawienie Tomasz Mróz odnosi do okresu od 1800 roku, rozpoczynając swoją pracę od analizy poezji Franciszka Karpińskiego, niemniej jednak warto zastanowić się, czy proces ten nie rozpoczyna się kilka lat wcześniej, gdy upadało państwo polskie, a idea mesjanizmu oraz koncepcja Polski-Feniksa podnoszącego się z popiołów powoli rodziły się na kartach, między innymi, rozpraw i poezji Woronicza. Zjawienie Emilki to przecież sam schyłek XVIII wieku, kilka lat przed ową cezurą, którą stawia Mróz, a wiele z jego tez odnosi się do utworu Woronicza. Wskazówkę, dotyczącą lektur platońskich Woronicza, można odnaleźć w Liście do przyjaciela z wygnania. Woronicz pisze: „w mej Platoń-

\footnotetext{
${ }^{15}$ J. P. Woronicz, Zjawienie Emilki..., s. 29.

${ }^{16}$ Z. Nerczuk, Obecność filozofii Platona w Polsce, „Toruński Przegląd Filozoficzny” 2003, nr 5/6, s. 57-73.

${ }^{17}$ T. Mróz, Platon w Polsce 1800-1950. Antologia, Zielona Góra 2010, s. 8-9.
} 
sko-Babińskiej Rzeczpospolitej / rozdając krzesła, ordery, zaszczyty [...]"18. Nesteruk i Rejman opatrzyły ten wers przypisem, w którym wyjaśniają koncepcję Platona ukazaną w Państwie. Badaczki wskazują również na wykorzystanie modelu społeczeństwa Platona przez Woronicza i kpinę autora z Rzeczypospolitej szlacheckiej ${ }^{19}$. Wybrane konteksty, zwłaszcza dotyczące organizacji społecznej z platońskiego Państwa, krążyły więc $w$ przekazach - mało prawdopodobne jest, iż pod koniec XVIII wieku (jeszcze przed wybuchem filhelleńskiej namiętności, rozpoczętej przez Gotfryda Ernesta Groddecka) były one czytane w oryginale, niemniej jednak mogły one krążyć w języku łacińskim bądź francuskim. Wydaje się więc, że nie tylko koncepcja społeczna, zawarta w Państwie, ale również sposób przedstawienia kosmicznego ładu, który wpływa bezpośrednio na moralny i etyczny porządek państwowy, był Woroniczowi znany.

Pozostaje jeszcze kwestia bohatera utworu, osoby przynoszącej wiadomość z zaświatów, a także odbiorców tego swoistego rodzaju objawienia. Platon opowiadał się za metafizyczną pielgrzymką ,wewnętrznego wzroku”, który pozwalał rozumowi ludzkiemu na oglądanie i poznanie sekretów natury, a taki „wewnętrzny wzrok” dany jest tylko nielicznym, wybitnym jednostkom ${ }^{20}$. Innym przysługuje tylko sen wynikający z natury biologicznej. Objawienie zaś prawd wszechświata może odbyć się dzięki odpowiedniemu przygotowaniu duszy, ćwiczeniu jej w cnocie i męstwie. Motyw odwiedzenia wszechświata przez Emilkę przypomina koncepcję z platońskich rozważań o podróżującej duszy.

Kraina wiecznej szczęśliwości odsłania przed Emilką swoje tajemnice. W momencie objawienia przekazuje je siostrze - mówi nie tylko o tym, że jest to kraina przodków, których poznała i od których przejęła mądrość wieloletnich pokoleń, ale także nie waha się powiedzieć całej prawdy o tym, iż widzi przyszłe losy wszystkich śmiertelników, widzi także losy Józi i swojej rodziny. Nie ukrywa tajemnic związanych z rzetelną obrazowością przedstawia Boga jako sprawiedliwego sędziego, który widzi wszystko, co dzieje się na ziemi i który za każdą wyrządzoną krzywdę odpłaci w niedalekiej przyszłości obfitością łask i wyzwoleniem. Emilka przekazuje również wskazówki siostrze, będące upomnieniami, dotyczące jasno określonego postępowania moralnego, zgodnego z wolą Boga i wypełniania Jego poleceń poprzez m.in. lektury ksiąg świętych.

\footnotetext{
${ }^{18}$ J. P. Woronicz, List do przyjaciela z wygnania, [w:] tenże, Pisma wybrane, s. 49.

${ }^{19}$ Tamże, s. 581.

${ }^{20}$ Warto przy okazji omawiania wspomnieć również o koncepcji Marsilio Ficinia, na którego wielki wpływ wywarły zarówno dzieła Platona, jak i koncepcja epistemologicznego aspektu marzeń sennych, przyjęta przez neoplatonika, Synezjusza. Wedle renesansowego uczonego, pamięć o rzeczach boskich sprawia, że dusza pragnie wyzwolić się z więzów ciała i powrócić do stanu boskości. Marzenie oniryczne miałoby więc pomóc w odczytaniu wskazówek dawanych przez boski, nieśmiertelny element duszy. Motyw snu wyobrażający złudę egzystencji był często rozwijany w pismach neoplatoników i u Marsilio Ficina. Zob.: A. Kuczyńska, Sztuka jako filozofia w kulturze renesansu wtoskiego, Warszawa 1988, s. 221 222; P. O. Kristeller, The Philosophy of Marsilio Ficino, transl. V. Conant, New York, 1943, s. 216-217; J. Zagożdżon, Sen w literaturze..., (rozdz. Proroczy charakter snów u Marsilia Ficina)s. 212-214.
} 
Można tu dostrzec dość wyraźne nawiązanie do Commentarii in Somnium Scipionis Makrobiusza. Również w tym dziele obecna jest dusza, której dane było zobaczyć wszechświat i która przyniosła stamtąd pożyteczne nauki. Scypion, podróżując po zaświatach, dowiaduje się, na jakie problemy powinien zwrócić uwagę i jak postępować, ażeby usprawnić państwo i znaleźć odpowiedni system polityczny. Dowiaduje się również, co zrobić i jak wykorzystać cnoty dobrego męża, aby pomóc republice. Afrykańczyk, dziadek Scypiona, który towarzyszy mu przez całą drogę, napomina go wielokrotnie, każe zaufać boskiemu natchnieniu i boskim radom. Nakazuje zapamiętać, iż za wszystkie uczynki złego człowieka czeka kara i wieczna zagłada oraz sprawiedliwa nagroda dla tego, kto odznaczał się cnotą i roztropnością. W dziele Woronicza również można odnaleźć cały spis potrzebnych cnót wyłożonych siostrze przez Emilkę. Stanowi on swoistego rodzaju przykazania dla ludzkości, a konkretnie dla narodu polskiego stojącego w obliczu niebezpieczeństwa i utraty niepodległości. Kto chce osiągnąć wolność i szczęście, musi działać według boskich zasad:

Bez Jego woli listek z drzewa nie upadnie,

Ani jeden robaczek losem swym nie władnie,

A los tylu narodów ludzkiego plemienia

Nie byłby godny Jego rządu i baczenia? ${ }^{21}$

Odpowiedź na pytanie, kiedy przyjdzie wolność, jest zakodowana zarówno w jednym, jak i w drugim dziele. Afrykańczyk radzi Scypionowi nie lękać się śmierci i unaocznia mu ułudę doczesnego rozgłosu. Emilka, ukazując się siostrze, również nie podaje konkretnych dat spełnienia obietnicy, lecz przyrzeczenie wyzwolenia niejako samo w sobie. W obydwu dziełach widać nie tylko element konsolacyjny czy moralizatorski, ale również zwycięstwo boskiej idei w panowaniu nad światem.

Warto zwrócić uwagę na posłańca, osobę, poprzez którą dochodzi do przekazania zaszyfrowanej wiadomości. Scypionowi ukazuje się dziadek, Afrykańczyk, który zabiera swojego wnuka w podróż w przestworza. Opowiada mu o przyszłości i objawia, iż zostanie konsulem, poprowadzi państwo rzymskie do zwycięstwa nad Kartaginą, jednocześnie napomina go, że nie powinien obawiać się śmierci, albowiem wielka nagroda czeka go po zgonie. Przedstawiony przez Makrobiusza posłaniec to dowódca, osoba, od której zależało bardzo wiele w państwie. Natomiast u Woronicza występuje mała, przedwcześnie zmarła dziewczynka. Jest to dość wyraźny znak — na równi postawiona zostaje mądrość w znaczeniu starożytnym, mądrość cnoty, rzymska virtus oraz niewinność i nieskazitelność duszy dziecka. Dostaje ona bardzo ważną misję objawienia się we śnie, ukazania wizji wszechświata i wysłania na Ziemię zaszyfrowanych znaków niezbędnych do odzyskania ukochanej wolności. Narodowi dano wskazówki, opatrzone odpowiednią, oniryczną konwencją i zawieszone w próżni domysłów i niedopowiedzeń. Faktem jest, iż punktem wyjścia wspólnym dla obu utworów jest moment krytyczny, graniczny, moment, który może zadecydować o dalszych losach

${ }^{21}$ J. P. Woronicz, Zjawienie Emilki..., s. 29. 
narodu: wojna z Kartaginą oraz rozbiory. Obydwu narodom - polskiemu i rzymskiemu - wysłany został znak przez zmarłą osobę. Woronicz umieścił Emilkę, małą dziewczynkę, w sytuacji lirycznej, która przypomina sytuację ze Snu Scypiona skomentowanego przez Makrobiusza. Inny jest posłaniec wiadomości (z jednej strony rzymskie męstwo, z drugiej zaś małe dziecko), niemniej jednak łączy te dwie postaci pewien kodeks zachowań - tylko dusza czysta i przygotowana może widzieć kosmos i przyszłość narodu. Takie zestawienie to częsty zabieg w literaturze porozbiorowej odwoływanie się do dzieł antycznych, które opiewają męstwo i powstanie z gruzów ${ }^{22}$.

\section{Problem profetyzmu w ZJAWIENIU EMILKI}

Kolejnym ważnym problemem w odczytywaniu utworu Woronicza jest profetyzm. Poemat Woronicza nie jest jednak proroctwem w ścisłym rozumieniu tego słowa nie wykazuje cech bezpośredniego przytaczania słów Boga w mowie niezależnej, ani nie jest usankcjonowany odpowiednim namaszczeniem osoby objaśniającej przesłanie boskie, czyli proroka ${ }^{23}$. Niemniej jednak, jeżeli spojrzeć na dzieło Woronicza w kontekście tradycji utworów profetycznych, dostrzec można wiele cech zbieżnych, nawiązań $^{24}$. Utworem, z którego dzieło Woronicza czerpie, jest Profecja księdza Marka Karmelity $^{25}$. Zazwyczaj wymienia się to anonimowe dzieło jako inspirację dla stworzenia przez Woronicza wizji historii Polski ${ }^{26}$. Można od razu ustalić typowe cechy utworu wieszczego wykorzystane zarówno w jednym, jak i w drugim dziele. Podstawowym celem, dla którego powstaje proroctwo, jest nawiązanie kontaktu sacrum z ludźmi po to, by przekazać ważną wiadomość. Emilka widzi w zaświatach wszystkie przeszłe i przyszłe wypadki i objawia je siostrze, w szerszym znaczeniu zaś — narodowi. Zainspirowany profecją księdza Marka, wykłada Woronicz swoją wizję historii Polski oraz obiecuje pomstę za krzywdy, jak również wyzwolenie narodu. Używa podobnej metaforyki, stylizuje momentami język na biblijny.

\footnotetext{
${ }^{22}$ Podobną sytuację można odnaleźć w Trenach Morelowskiego, w których autor nawiązuje bezpośrednio do Eneidy Wergiliusza. Zob. O. Szadkowska, Sen jako technika poetycka. Motyw marzenia onirycznego w Śnie Józefa Morelowskiego, „Humanistyka XXI wieku” 2012, nr 1 (3), s. 219-228.

${ }^{23}$ P. Kładoczny, Proroctwa chrześcijańskie jako gatunek mowy, Zielona Góra 2004, s. 90-99.

${ }^{24}$ J. Gorzelana, Niektóre językowe cechy..., s. 223. Do takich utworów zalicza przepowiednie Wernyhory, kalendarze i prognostyki epoki saskiej, a także odę XI Adama Naruszewicza, Prognostyk na rok Pański 1775. O proroczej wymowie utworu Woronicza pisze także A. Drogoszewski, Interpretacja „Zjawienia Emilki” a mesjanizm Woronicza, „Pamiętnik Literacki” 1947, s. 55-56 oraz L. Kamykowski, Do źródet mesjanizmu Woronicza, „Pamiętnik Literacki” 1932, s. 285-290.

${ }^{25}$ Profecja Księdza Marka Karmelity, [w:] Literatura barska. Antologia, oprac. J. Maciejewski, Wrocław 1976, s. 3-5.

${ }^{26}$ Według Emanuela Rostworowskiego, Woronicz bezpośrednio zaczerpnął ten obraz z proroctwa ks. Marka Karmelity, zob. Ksiadz Marek i proroctwo polityczne doby radomsko-barskiej, [w:] Przemiany tradycji barskiej, red. Z. Stefanowska, Kraków 1972. Zwracają na to uwagę w swoich opracowaniach zarówno M. Nesteruk i Z. Rejman, jak i J. Gorzelana. Inną wersję podał P. Żbikowski, wedle którego uruchamiane w Zjawieniu Emilki konteksty dadzą się wytłumaczyć poprzez polityczne odwołania, a nie dzięki proroctwom i prognostykom. Zob. J. P. Woronicz, Wstęp, [w:] tenże, Pisma wybrane, s. XXIX.
} 
Wypadało miast dobyć — zatrąbiony w rogi

Pękły bramy i mury bez szturmu, pożogi [...]

Zbrodnia kilku narodów nie obala sprawy

Ni uprawnienia najeźdźców waszych rozbój krwawy [...]

Dziś to zdziała [Bóg] co u was wieków miljony

Wyroków Jego księgę w ręku swym trzymacie $[\ldots]^{27}$

Przypomina to apokaliptyczny opis, który można zaobserwować w Profecji Księdza Marka Karmelity. W anonimowym dziele przedstawiona jest personifikacja Polski, czyli Feniks podnoszący się z popiołów, oraz apokaliptyczna wizja krwawego miecza zwisającego nad głowami ludzkości, a także obraz strasznej burzy i „cnej góry złotym otoczonej kołem”, która „ma Bogu ufać nisko bijąc czołem”28. Utwór ten jest krótką profecją, napisaną pod wpływem natchnienia ${ }^{29}$, posiada wiele cech chrześcijańskiej wizji Apokalipsy Świętego Jana. Zarówno w Profecji Księdza Marka Karmelity, jak i w Zjawieniu Emilki widać również zachowane prawa rządzące jasnowidztwem. Wizje nachodzą podczas snu, obecna jest osoba nadprzyrodzona, wszystko odbywa się o specjalnej godzinie, po prezentacji obrazów wizyjnych następuje wyjaśnienie i interpretacja przedstawionego świata. Zarazem jednak należy dostrzec również różnice tych dwu tekstów. Profecja księdza Marka Karmelity nie zawiera elementu moralizatorskiego ani upominającego, nie ma w niej żadnych wskazówek dotyczących dobrego życia czy cnoty, cała profecja oparta jest na krótkim przekazie dotyczącym profetycznej wizji, bez stwarzania sytuacji lirycznej. Pojawia się za to starotestamentowy motyw narodu wybranego, udręczonego i zmartwychwstałego. Utwór Woronicza z kolei jest dziełem zbyt wielopłaszczyznowym, zbyt wiele w nim poziomów interpretacji i mozaiki konwencji, ażeby nazwać go utworem proroczym. Tradycja utworu Woronicza jest bowiem różnorodna: zarówno antyczna, jak i chrześcijańska. Kilka cech utworu wskazuje na inspirację profecją księdza Marka Karmelity, zwracają na to uwagę badacze twórczości Woronicza i jest to ważny trop w poszukiwaniu interpretacji Zjawienia Emilki. Niemniej jednak chciałam zwrócić uwagę na oniryczną figurę poetycką, którą Woronicz się posługuje, a która do tej pory nie była analizowana.

\section{Woronicz I WergiliusZ}

Chciałabym również zwrócić uwagę na powiązania z Wergiliuszem obecne w Zjawieniu Emilki. Wielokrotnie Woronicz odwoływał się do twórczości Marona, czyniąc go swoim mistrzem, wybierając z jego dzieł nie tylko wartości odnoszące się do cnoty męstwa, virtus czy dumy narodowej, ale również sięgając głębiej, do części mistycznej, profetycznej, której nie brakuje w Wergiuliszowych eklogach. Zofia Rejman w Poecie $i$ kaptanie zwraca uwagę, że Wergiliusz to ulubiony poeta Woronicza, najchętniej go i czytał i parafrazował. Powołuje się ona również na pogląd Franciszka Gucwy — do-

\footnotetext{
${ }^{27}$ J. P. Woronicz, Zjawienie Emilki, s. 31, 38-39.

${ }^{28}$ Profecja Księdza Marka Karmelity, s. 3.

${ }^{29}$ Por. E. Rostworowski, dz. cyt., s. 107-165.
} 
strzegł on w Woroniczu i Wergiliuszu „dwie pokrewne natury”, w których „uczucie zawsze brało górę nad rozsądkiem”. Dostrzega analogię pomiędzy „,romantykiem starożytnego Rzymu” i „pierwszym polskim romantykiem”, niemniej jednak nie ogranicza się jedynie do analizy utworów nawiązujących do ich wspólnego, traumatycznego przeżycia - wygnania. Zwraca przede wszystkim uwagę na inspiracje poetyckie, sposób obrazowania, operowanie podobnymi parafrazami. Rozważając więc antyczne konwencje w Zjawieniu Emilki nie sposób nie podjąć tematu dzieł Wergiliusza ${ }^{30}$.

Eneida $i$ Ekloga IV to dwa najbardziej charakterystyczne utwory przywołane w Zjawieniu Emilki. Odwołania do rzymskiego poety pojawiają się już na samym początku utworu w postaci motta: „Tempus erat, quo prima quies mortalibus aegris / Incipit, et dono divum gratissima serpi”31 — „Był to czas, kiedy się dla biednych ludzi / Pierwszy zaczyna spoczynek, ten z łaski / Bogów najsłodszy"32. Słynne zdanie z II księgi dotyczy słodkiego snu zsyłanego przez bogów i dającego wytchnienie choremu (w sensie: ułomnemu) ciału człowieka. Woronicz umieścił jako motto swojego poematu zdanie, które pojawia się praktycznie na początku epopei. Jest to moment ucieczki Eneasza z Troi. Bohater widzi we śnie zjawę Hektora, który namawia go do opuszczenia rabowanego i upadającego miasta. Koncepcja zmarłego, który daje Eneaszowi wskazówki przez sen, została przeniesiona na grunt polski, a fakt, że cytat pochodzi z najważniejszego utworu w dziejach narodu rzymskiego, nadaje mu dodatkowo nobliwego charakteru. Wszystko spełnia się, podobnie jak w Commentarii in Somnium Scipionis. Postać wielkiego wojownika Hektora, który pośmiertnie udziela rad młodszemu bohaterowi i pokazuje mu właściwą drogę, staje się tym samym klamrą łączącą dwa światy — świat żywych i zmarłych. Znaczenie i waga zsyłania informacji poprzez zmarłą osobę jest więc bezsprzeczna, dodatkowo przypieczętowana cytatem z epopei rzymskiej.

Motyw podróży zza świata, który prezentują postacie Hektora i Eneasza, sięga homeryckiej Odysei. Widoczne jest u Wergiliusza nawiązanie do zajścia w zaświaty Odyseusza i jego rozmowy ze zmarłymi. Tym samym Wergiliusz potwierdza czerpanie z utworu Homera motywu katabazy oraz spotkania z nieżyjącymi już bliskimi lub postaciami wielkich mężów, którzy dają bohaterowi wskazówki i przestrogi. Wspólna dla Homera i Wergiliusza jest również koncepcja marzenia onirycznego. W Odysei miejsce zamieszkania Hypnosa, boga snów, znajdowało się bardzo blisko Tanatosa, śmierci. Księgę XXIV otwiera opis podróży zmarłych zalotników. Dusze podróżują skrajem Okeanosu, skąd rozpościera się widok na rezydencję dusz umarłych ${ }^{33}$. Również u Wergiliusza motywy snu i śmierci są z sobą nierozerwalnie związane.

\footnotetext{
${ }^{30}$ Z. Rejman, Jan Pawet Woronicz, Poeta i kaptan, Chotomów 1992, s. 126-127. Również Tadeusz Sinko w pracy Antyk $w$ literaturze polskiej wspomina o oddziaływaniach poezji Wergiliusza (ze szczególnym uwzględnieniem Eneidy) na twórczość Woronicza, zob. T. Sinko, Antyk w literaturze polskiej, Warszawa 1988, s. 22, 489-490.

${ }^{31}$ Motto w J. P. Woronicz, Zjawienie Emilki..., s. 26.

${ }^{32}$ Wergiliusz, Eneida, przekł. Z. Kubiak, Warszawa 1987, s. 76.

${ }^{33}$ Odyseja, przekł. L. Siemieński, wstęp Z. Abramowiczówna, oprac. i objaśn. J. Łanowski, Wrocław 1992, BN II 21, s. 452 (i nast.).
} 
Koncepcja zakładająca nierozerwalną przez śmierć potrzebę kontaktu żywych z umarłymi, pojawia się również w Boskiej Komedii Dantego, który bezsprzecznie nawiązywał do antycznych utworów. Szczególnie interesujące wydają się ustalenia badaczy dotyczące platońskich korzeni utworu Dantego. Na ich podstawie można wskazać pewną analogię pomiędzy mitem Era i wizją dantejskiego Piekła. Zarówno w utworze Platona, jak i u Dantego, widać swoistego rodzaju wizję w wizji, kosmiczny obraz przypominający swą strukturą szkatułkę. Dusza odwiedzająca kolejne stopnie kosmosu (jak w przypadku mitu o Erze) bądź kolejne kręgi piekielne (jak w Piekle), przenosi się do świata uporządkowanego według określonych reguł, gdzie odbywa się sąd nad duszami, kategoryzowanie i segregacja. Ponadto, w Boskiej Komedii potępione dusze miały do czynienia jedynie z odbiciem idei w postaci zsyłanych obrazów, podobnie jak platońskie dusze, które w konfrontacji z kosmicznym widowiskiem mogły jedynie dostrzec odbicie wieszczych idei ${ }^{34}$. Należy wziąć również pod uwagę możliwość spotkania w zaświatach bliskiej osoby i uzyskania od niej konkretnych wskazówek dotyczących dalszego postępowania. Zjawienie Emilki pod tym względem czerpie wiele $\mathrm{z}$ antycznych wzorców, niemniej jednak warto odnotować pewne analogie z Boskq Komediq, chociażby ze względu na zależność między utworami Platona i Dantego. Wykorzystanie motywu spotkania zmarkej osoby i swoistego rodzaju katabazy do podziemi to kolejne nawiązanie do tradycji starożytnej, jak również dowód na to, jak wiele poemat ten zawdzięcza tradycji antycznej w najróżniejszych odmianach: filozoficznej (neoplatonizm), krytycznoliterackiej (Makrobiusz) i poetyckiej (Wergiliusz i Homer).

Obecność zaś IV Eklogi w poemacie Woronicza jest dość oczywista. Najbardziej niejasna, tajemnicza i enigmatyczna ze wszystkich Wergiliuszowych bukolik przez wieki była wykorzystywana przez chrześcijańskich interpretatorów. Fakt, że umieszczona została wśród utworów pasterskich, w których bohaterowie opowiadają o swoich miłosnych przygodach, dodaje jej jeszcze zagadkowości. Odczytanie twórców chrześcijańskich było jednoznaczne: wspomniane przez Wergiliusza narodzenie Dziecka, zwiastujące nowy porządek świata i odrodzenie ludzkości, było, rzecz jasna, tłumaczone przyjściem na świat Chrystusa ${ }^{35}$. Podobnie postrzegane były powrót złotego wieku oraz zapowiedź wielkich zmian w świecie, które dokonają się za sprawą Dziecka. Taki charakter czwartej bukoliki umieszcza ją w tradycji utworów profetycznych, zwiastujących nowy porządek świata ${ }^{36}$. Dla moich rozważań ważne jest samo ujęcie tej tematyki

\footnotetext{
${ }^{34}$ Jest to koncepcja przyjęta przez Johna Alexandra Stewarta. Według niego, ogólny zarys Boskiej Komedii zawarty jest w platońskim micie Era. Zob. J. A. Stewart, The Myth of Er, [w:] taż, The Myths of Plato, Carbondale III, Londyn 1905, s. 157-178.

${ }^{35}$ Abramowiczówna we wstępie do Bukolik i Georgik pisze, że zrozumiałym jest, iż chrześcijanie odnieśli to do Chrystusa, za dziewicę mając Maryję, lekceważąc zaś wzmianki o Apollonie. Stąd cześć, którą otoczony był Wergiliusz w średniowieczu i legendy, które wokół niego się pojawiły, zob. Wstęp, [w:] Wergiliusz, Bukoliki i Georgiki, przekł. i oprac. Z. Abramowiczówna, Wrocław 1953, BN II 83, s. XXIV.

${ }^{36} \mathrm{Zdaniem} \mathrm{Z}$. Ambramowiczówny, IV Ekloga wyrażona jest stylem podniosłym, natchnionym, jest to utwór, wokół którego piętrzą się zagadki: „utwór ten przepojony jest wiarą w nadejście jakiegoś momentu przełomowego, rozpoczęcia się nareszcie po okrutnej epoce walk bratobójczych, ery pokoju, wytchnienia i sprawiedliwości”. Zob. Wstęp, [w:] Bukoliki..., s. XXIII-XVI.
} 
i wpisanie jej w konwencję profetyzmu, do którego sięgnął później Woronicz. Również wykorzystanie motywu Dziecka wraz z całą semantyką tej postaci (niewinność, czyste serce, nowe życie, odrodzenie), pozwala na ustalenie pewnej analogii między tymi dwoma utworami i umieszcza je w podobnym kręgu literackim stylizowanym na profecję wśród dzieł wieszczących odrodzenie dla świata czy narodu wybranego. Należy również zwrócić uwagę na fakt, że ze względu na przepowiednię nadejścia wybranego Dziecka oraz powrotu złotego wieku, Wergiliusz uważany był za autorytet, a niektórzy widzieli w nim nawet proroka ${ }^{37}$. Warto przytoczyć ostatnie zdania z Eklogi IV:

Zacznij, chłopczyku, matkę rozpoznawać uśmiechem,
Ona wiele cierpiała przez dziesięć długich miesięcy,
Zacznij! Do kogo rodzice nie uśmiechnęli się, tego
Bóg nie zaszczyca stołem ani bogini łożem ${ }^{38}$.

Szczególnej wymowy nabiera ten utwór w tłumaczeniu Zygmunta Kubiaka. Jak gdyby przeplatają się z sobą plany starożytnego obrządku i chrześcijańskiej wiary, a wszystko dopełnia się w jakimś nienaturalnym pośpiechu („takie wieki, biegnijcie - krzyknęly swoim wrzecionom / Parki w niewzruszonej mocy losów zgodne / Wejdź już — bo czas jest bliski — w swoje wielkie zaszczyty") i wśród chaotycznych przygotowań na nadejście wielkiej chwili. Charakterystyczna w tym fragmencie jest postać cierpiącej przez dziesięć miesięcy matki, która dzięki uśmiechowi rozpoznaje swoje dziecko. Cierpienie, oczekiwanie na czyjeś nadejście, figura dziecięcia oraz język stylizowany na przepowiednię - to wszystko sprawia, że Ekloga $I V$ jest utworem, do którego bardzo często nawiązują inni twórcy. Wykorzystanie pieśni sybillińskiej Wergiliusza przez Woronicza jest wyjątkowe, nie jest wyrażone wprost. Jedynie dzięki wnikliwej lekturze można rozpoznać cechy wspólne obu utworom: stylizację na profecję, zapowiedź pokoju i stabilizacji po okresie wojny i chaosu, a także charakterystyczną figurę dziecka — niewinnej postaci, która zwiastuje nowy porządek. Ponadto Woronicz chętnie wykorzystał motyw pieśni sybilińskiej w utworze Świątynia Sybilli — jednym ze swoich najbardziej znanych dzieł. Proroctwo Sybilli rozpoczynające się od słów „Wy przecie niepobaczni na wyroki święte / Rozwodzicie mrukliwie żale nieujęte" przeniesione zostaje przecież do Zjawienia Emilki. Woronicz wyrá́nie wpisuje historię narodu w plany Opatrzności. Nawiązanie do proroctwa Wergiliusza nie jest więc ani przypadkowe, ani jednorazowe ${ }^{39}$.

Przyglądając się więc bliżej tradycji utworów profetycznych, z których korzystał Woronicz i którym nadał swój własny, charakterystyczny rys w Zjawieniu Emilki, do-

\footnotetext{
${ }^{37}$ Według Tadeusza Sinki, Ekloga IV obdarzyła Wergiliusza pośmiertną sławą proroka, mędrca i czarodzieja, wywołała również w nowszych czasach istną powódź literatury objaśniającej, zob. Wstęp, [w:] Wergiliusz, Eneida, przekł. T. Karyłowski, wstępem i objaśnieniami opatrzył T. Sinko, Wrocław 1950, BN II 29.

${ }^{38}$ Pieśn Sybillinska (Ekloga IV), [w:] Z. Kubiak, Literatura Greków i Rzymian, Warszawa 2003, s. 433.

${ }^{39}$ J. P. Woronicz, Wstęp, [w:] tenże, Pisma wybrane, s. XLI.
} 
chodzę do wniosku, iż była to tradycja bilateralna, antyczna i chrześcijańska. Z jednej strony widać bowiem kilka cech profetycznego utworu — postać zmarłej Emilki opowiada o przyszłych wydarzeniach, prezentuje wizję przypominającą apokalipsę, przychodzi do zmarłej siostry o specjalnej porze. Bezsprzecznie Woronicz zapożyczył $z$ Profecji Księdza Marka temat odrodzenia się narodu polskiego z popiołów ${ }^{40}$ i osiągnięcie niepodległości. Podobny jest również sposób obrazowania, czerpiący ze starotestamentowych opisów wizyjnych. Wszystko jednak jest pewną stylizacją na profecję, bardziej stylizacją niż prawdziwą przepowiednią. Woronicz nie stworzył utworu, który przytacza bezpośrednio słowa Boga, użył za to odpowiednich środków artystycznych, by napisać utwór alegoryczny, zaszyfrowany, ujęty w ramy snu, poemat, który będzie sugerował pewną rzecz, a nie ją objawiał. Nie można lekceważyć wpływu starożytnej filozofii na ten poemat, wszystkie bowiem tropy wiodą do koncepcji duszy, której podczas snu dane jest oglądać Boga i poznać Jego myśl, duszy, która ulatuje. Wiąże się to ściśle z pojęciem duszy przygotowanej na taką pielgrzymkę, duszy męskiej, roztropnej, wstrzemię́liwej i sprawiedliwej. Te cnoty decydują o odpowiednim przygotowaniu na spotkanie z Bogiem, czy to bezpośrednie, czy poprzez pośrednika. Obserwacja universum, dzięki „wewnętrznemu wzorkowi”, daje niezwykłą władzę, władzę, z której skorzystać mogą tylko cnotliwi. Dlatego i w Zjawieniu Emilki, i w Śnie Scypiona, i w micie Era do obejrzenia wszechświata we śnie zaproszeni zostali wybrani. Tylko im można objawić szczegóły kosmogonii ukształtowanej według idei Bożej. Wydaje się, iż Zjawienie Emilki nie jest tekstem, w którym dokonana została przemiana wartości zaczerpniętych z antyku na wartości chrześcijańskie. Poemat Woronicza niczego nie przekształca, poeta jest świadomy korzeni konwencji, którą chce operować, czyli starożytnej konwencji wędrówki duszy nad universum. Woronicz umieszcza całą tę tradycję w swoim dziele i wykorzystuje ją do alegorycznego przedstawienia losów Rzeczypospolitej. Przesłanie polityczno-etyczne jest bardzo ważne ${ }^{41}$.

Niemniej jednak nie powinna ujść uwadze także forma i konwencja, ponieważ jest nie tylko interesująca, ale także pozwala na nowe odczytanie i nowe interpretacje tego zagadkowego utworu. Przy omawianiu przez badaczy Zjawienia Emilki Woronicza nie pojawia się problematyka platońska, brakuje również rozważań wokół Makrobiusza i komentarza do Snu Scypiona, a jest to niezwykle ciekawy trop interpretacyjny i pozwala ukazać dzieło Woronicza w kontekście antycznych teorii dotyczących marzeń sennych. Czy Woronicz celowo umieścił antyczne wskazówki, czerpiąc z Platona, Wergiliusza, czy jest to raczej domniemanie wykorzystania pewnego motywu? Ciężko jednoznacznie odpowiedzieć na to pytanie. Idee platońskie funkcjonowały w sferze pewnych przeświadczeń filozoficznych, przyjętych przez chrześcijaństwo. Widać to wyraźnie nie tylko w Zjawieniu Emilki, ale również w utworze Emilka. Sielanka. W komen-

\footnotetext{
${ }^{40}$ Profecja Księdza Marka Karmelity..., s. 4.

${ }^{41} \mathrm{Na}$ polityczny aspekt Zjawienia Emilki zwraca uwagę Żbikowski w pracy „[...] bólem śmiertelnym ściśnione mam serce". Rozpacz oświeconych. Uźródet przetomu w poezji polskiej 1793-1805. Cyt. za M. Nesteruk, Z. Rejman, Wstęp, [w:] J. P. Woronicz, Pisma wybrane, s. XXX.
} 
tarzu do wersów „z tych spróchniałych kości i piszczelów / wskrzesi na zbójców świata krzywd naszych mścicielów”ł2 Rejman i Nesteruk zwracają uwagę, że w twórczości Woronicza motywy antyczne zostają połączone z biblijną wizją wskrzeszenia zmarłych. Analogicznie, Zjawienie Emilki prezentuje łączność między światem chrześcijańskiej interpretacji: proroczej, mesjanistycznej oraz tej antycznej, z jednej strony zapożyczonej od Wergiliusza (bezpośrednio poprzez motto), z drugiej zaś, co mniej oczywiste, z Platona (pośrednio przez wizję podobną do wizji zmarłego Era w Państwie).

Można pokusić się o dostrzeżenie nowego wątku interpretacyjnego, związanego z drugą twarzą antyku w oświeceniu. Druga twarz oświecenia (która rozwinęła się w literackich tekstach w okresie porozbiorowym) ujawnia się w momencie, w którym twórcy zaczynają uciekać w sytuację liryczną tworzoną ze $\mathrm{snu}^{43} \mathrm{i}$ pozwala na odkrycie nowych związków oświecenia z antykiem. Antyk w oświeceniu kojarzony zazwyczaj z satyrami, komediami obyczajowymi, traktatami o teorii poezji, nabiera przy Zjawieniu Emilki Woronicza innego wydźwięku. Odnosi się bowiem do tradycji teorii marzeń sennych. Woronicz, swoją twórczością reprezentując schyłek epoki oświecenia, sięgnął po antyk magiczny, oniryczny, po antyk, który czerpał również z profetyzmu. Jego samego nazywano przecież pierwszym prorokiem nowoczesnej Polski ${ }^{44}$. Tendencje antyoświeceniowe w oświeceniu? Sięgając do źródeł, przywołując niektóre konteksty z dialogów Platona, dzieł neoplatoników, biorąc do ręki mało znane księgi Synezjusza ${ }^{45}$, można odkryć wiele nieporuszanych do tej pory wątków. Sposób przedstawienia kosmosu w Zjawieniu Emilki może mieć bowiem również platońską inspirację, tym bardziej, że dzieło powstało w 1795 roku, a więc jedynie chwilę przed cezurą postawioną przez Tomasza Mroza w książce o Platonie w Polsce. Pytanie o wpływy greckie w tym okresie nie jest więc pytaniem o oświeceniowe fascynacje Platonem, lecz o zamiłowania platońskie w romantyzmie, a te były już bardzo silne. Warto zastanowić się,

\footnotetext{
${ }^{42}$ J. Woronicz, Emilka. Sielanka, [w:] tenże, Pisma wybrane, s. 47.

${ }^{43}$ Warto wymienić chociażby utwory pisane w więzieniu przez Kołłątaja i Niemcewicza, w których tematyka marzeń sennych wysuwa się na pierwszy plan. Zob. H. Kołłątaj, Nad snami, czyli nad marzeniami nocnymi moje uwagi, w Józefsztadzie, dnia 8 i 9 sierpnia 1796, Kraków 2007 oraz J. U. Niemcewicz, Pamiętniki czasów moich, t. 1, Warszawa 1958.

${ }^{44}$ Ryszard Przybylski w książce Klasycyzm, czyli Prawdziwy koniec Królestwa Polskiego pisze: „Chrześcijaństwo [...] stało się warownią, która zastąpiła nam państwo. Było to wydarzenie o epokowym znaczeniu dla Polski i dlatego Jan Paweł Woronicz został pierwszym prorokiem nowoczesnej Polski”, zob. R. Przybylski, Klasycyzm, czyli Prawdziwy koniec Królestwa Polskiego, Warszawa 1983, s. 391.

${ }^{45} \mathrm{~W}$ traktacie De insomniis przedstawił on siłę wyobraźni (vis imaginativa) jako najpierwszą zasadę organizującą kosmos, która niczym lustro odbija myśl boską i umieszcza ją w niższych warstwach wszechświata. Dzięki temu ludzka jaźń, która rozpoznawała w niższej postaci swoje odbicie, wyruszała w podróż do ludzkiego ciała, po drodze przechodząc stopniowo przez strefę gwiazd, po czym pogrążała się w wilgoci i stawała się kłębem oparów, aż do widzialności i uzyskania materialnej szaty. $Z$ tej całej kosmogonicznej koncepcji duszy ludzkiej wynikałoby, iż kolejne warstwy jej „okrycia” stanowiły odbicie kosmicznego ładu wszechrzeczy, ponieważ podczas całej wędrówki duszy do materialnego ciała, każda z planetarnych mocy, które dusza „odwiedzała”, przekazała jej jakąś cząstkę siebie. Zob. A. Fitzgerald, The essays and hymns of Synesius of Cirene, Londyn 1930, s. 336.
} 
czy nie można mówić o preromantycznych inspiracjach Platonem. Zjawienie Emilki czeka więc na ponowne odkrycie, bowiem wydaje się, iż odczytanie tego utworu jedynie w kontekście mesjanistycznym i historiozoficznym (jako utworu zapowiadającego preromantyzm) mogło by być niewystarczające.

Olga Szadkowska

The Oneiric Journey of the Death

About ZJaWIenIE EMiLKI of Jan PaWee Woronicz

\section{Summary}

This article is considering the journey of the death in Woronicz's book, Zjawienie Emilki. Work of Jan Paweł Woronicz includes vision of death girl, who tells her dreaming sister a story about things she has seen in heaven. This specific type of journey (after death) has it ancient provenience. This article is considering Plato's myth of Er and Dream of Scipio as a two texts which have huge influence on Woronicz's work. Furthermore this article presents tradition of prophetic texts as Profecja Księdza Marka Karmelity. It shows that not only Polish tradition (called preromantic), but also Ancient literature got impact on 18 th century poetry. 